\title{
VISUALISASI DAN ANALISIS DATA BUNUH DIRI
}

\author{
Irwan Setiawan*1 \\ ${ }^{1}$ Jurusan Teknik Komputer dan Informatika - Politeknik Negeri Bandung \\ Email: ${ }^{1}$ irwan@jtk.polban.ac.id \\ *Penulis Korespondensi
}

(Naskah masuk: 21 Maret 2020, diterima untuk diterbitkan: 08 Juni 2021)

\begin{abstract}
Abstrak
Bunuh diri merupakan salah satu permasalahan kesehatan publik. Kematian yang disebabkan oleh tindakan bunuh diri banyak terjadi di seluruh dunia. World Health Organization (WHO) melaporkan bahwa tindakan bunuh diri terjadi sekitar satu juta kejadian setiap tahunnya. WHO menyediakan basis data kematian yang disebabkan karena bunuh diri, namun parameter dan diagram yang disediakan pada basis data tersebut tidak dapat dikustomisasi untuk analisis lebih lanjut. Exploratory Data Analysis merupakan teknik analisis yang menekankan penyajian data dalam bentuk grafik yang dapat mempermudah analis dalam menemukan pola-pola tersembunyi dalam data. Teknik ini sangat efektif digunakan untuk menganalisis data yang memiliki volume yang besar dan varian data yang banyak. Penelitian ini ditujukan untuk melakukan visualisasi dan analisis data kematian yang disebabkan oleh bunuh diri dengan menggunakan data yang disediakan oleh WHO untuk menemukan pola dan tren kejadian bunuh diri dari berbagai negara dan benua agar dapat membantu pihak-pihak yang berkepentingan dalam mendeteksi dan merencanakan tindakan pencegahan kejadian bunuh diri. Metode penelitian terbagi kedalam tiga tahapan, yaitu persiapan data, Exploratory Data Analysis, dan penarikan kesimpulan. R Studio digunakan sebagai perangkat lunak untuk pengolahan dan visualisasi data. Hasil yang didapatkan dari penelitian ini adalah teknik Exploratory Data Analysis sangat efektif untuk mengeksplorasi data dan menemukan pola-pola tersembunyi dalam data.

Berdasarkan hasil analisis, Jepang merupakan negara yang memiliki kejadian bunuh diri paling banyak. Temuan yang didapatkan adalah secara umum jumlah kejadian bunuh diri memiliki tren yang meningkat. Pada tahun 1998 terjadi lonjakan kejadian bunuh diri yang sangat signifikan di negara-negara Asia. Negara yang paling banyak mengalami kejadian bunuh diri adalah Jepang. Pola pelaku bunuh diri di benua Afrika berbeda dengan benua lainnya. Kelompok usia diatas 75 tahun merupakan kelompok usia dengan jumlah bunuh diri paling banyak. Terjadi tren peningkatan kejadian bunuh diri pada kelompok umur 5-14 tahun. Temuan-temuan yang didapatkan dari penelitian ini dapat dimanfaatkan untuk kebutuhan perencanaan pencegahan kejadian bunuh diri dan meningkatkan kewaspadaan terhadap terjadinya risiko bunuh diri, terutama pada kelompok umur diatas 75 tahun dan 5-14 tahun.
\end{abstract}

Kata kunci: exploratory data analysis, visualisasi data, tren bunuh diri, analisis bunuh diri

\section{VISUALIZATION AND ANALYSIS OF SUICIDE DATA}

\begin{abstract}
Suicide is a public health problem. Deaths caused by acts of suicide occur throughout the world. The World Health Organization (WHO) reports that suicides occur in around one million incidents each year. WHO provides a database of deaths due to suicide, but the parameters and diagrams contained in that database cannot be customized for further analysis. Exploratory Data Analysis is an analytical technique that emphasizes data presentation in a graphical form that can make it easier for analysts to find hidden patterns in the data. This technique is beneficial for analyzing data with a large volume and many data variants. This research aims to visualize and analyze data on deaths caused by suicide by using data provided by WHO to find patterns and trends in suicide events from various countries and continents to help the parties concerned in detecting and planning preventive suicide actions. The research method is divided into three stages: data preparation, Exploratory Data Analysis, and concluding. $R$ Studio is used as software for data processing and visualization. The results obtained from this study are Exploratory Data Analysis techniques, which are useful for exploring data and discovering hidden patterns in data. Based on the results of the analysis, Japan is a country that has the most suicide. The finding is that in general, the number of suicides has an upward trend. In 1998 there was a very significant surge in suicides in Asian countries. Japan is the country that experiences the most suicide. The pattern of suicide in Africa is different from other continents. The age group above 75 years is the age group with the highest number of suicides. There is a trend of an increase in the incidence of suicide in the 5-14 years age group. The findings
\end{abstract}


obtained from this study can be utilized for the needs of planning suicide prevention events and increasing awareness of the occurrence of suicide risk, especially in the age group above 75 years and 5-14 years.

Keywords: exploratory data analysis, data visualization, suicide trend, suicide analysis

\section{PENDAHULUAN}

Bunuh diri merupakan salah satu permasalahan kesehatan publik. Walaupun bunuh diri bukan disebabkan karena penyakit, kematian yang disebabkan karena tindakan bunuh diri banyak terjadi di seluruh dunia (Turecki et al. 2019; Lutz, Mechawar, and Turecki 2017). Kejadian bunuh diri diseluruh dunia mencapai 1 juta orang pertahun (Turecki and Brent 2016). Walaupun belum ada algoritma yang dapat memprediksi bunuh diri, sangatlah penting untuk mengetahui tren, sebaran, dan faktor-faktor yang dapat menyebabkan terjadinya tindakan ini agar dapat membantu dalam mendeteksi dan merencanakan tindakan pencegahan (Turecki and Brent 2016).

Exploratory Data Analysis merupakan teknik yang mengekplorasi data dalam bentuk grafik dan atau peta untuk mempermudah manusia dalam menganalisis dan menemukan pola-pola tersembunyi dalam data (Jebb, Parrigon, and Woo 2017; Wongsuphasawat, Liu, and Heer 2019). Beberapa penelitian yang menggunakan teknik Exploratory Data Analysis adalah sebagai berikut, (Burke et al. 2018) menggunakan exploratory data mining untuk mengidentifikasi dan mengklasifikasikan rencana dan perilaku bunuh diri, (Ammerman et al. 2018) menganalisis hubungan antara pendidikan masa kecil dengan perilaku bunuh diri, (Ludwig et al. 2019) klusterisasi bunuh diri, dan (Preti and Lentini 2016) model prediksi untuk bunuh diri.

WHO sebagai organisasi kesehatan dunia menyediakan basis data kematian yang disebabkan oleh berbagai penyebab, salah satunya adalah karena bunuh diri. Basis data tersebut dapat dilihat pada http://apps.who.int/healthinfo/statistics/mortality/wh odpms/. Pada halaman tersebut, pengguna diharuskan memilih parameter untuk ditampilkan dalam bentuk diagram atau tabel. Namun parameter dan diagram yang disediakan tidak dapat dikustomisasi untuk analisis lebih lanjut.

Permasalahan yang akan diselesaikan dalam penelitian ini adalah tidak tersedianya fitur visualisasi data bunuh diri yang dapat dikustomisasi pada situs yang disediakan WHO menyebabkan data yang ada menjadi kurang termanfaatkan.

Tujuan dari penelitian ini adalah melakukan visualisasi dan analisis data kematian yang disebabkan oleh bunuh diri dengan menggunakan data yang disediakan oleh WHO untuk menemukan pola dan tren kejadian bunuh diri dari berbagai negara dan benua agar dapat membantu pihak-pihak yang berkepentingan dalam mendeteksi dan merencanakan tindakan pencegahan kejadian bunuh diri.

Artikel ini disusun dalam empat bagian, bagian pertama merupakan bagian Pendahuluan yang menjelaskan latar belakang dan tujuan penelitian. Setelah bagian Pendahulan, terdapat bagian Metode Penelitian yang menjelaskan mengenai metode penelitian yang digunakan. Selanjutnya adalah bagian Hasil dan Pembahasan yang menjelaskan mengenai hasil dan pembahasan yang meliputi hasil persiapan data dan visualisasi dan analisis data bunuh diri. Pada bagian akhir artikel ini, terdapat bagian Kesimpulan yang menjelaskan mengenai kesimpulan yang didapatkan berdasarkan temuan data dan pola yang terdapat pada data.

\section{METODE PENELITIAN}

Sumber data pada penelitian ini diambil dari http://apps.who.int/healthinfo/statistics/mortality/wh odpms/. Seperti dapat dilihat pada Gambar 1, terdapat tiga tahapan utama yang dilakukan dalam penelitian ini, yaitu Persiapan Data, Exploratory Data Analysis, dan Insights.

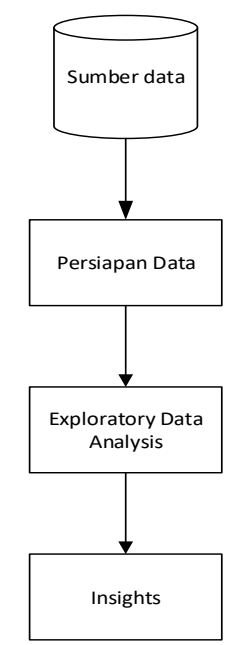

Gambar 1 Metode visualisasi dan analisis data berikut:

Uraian dari setiap tahapan adalah sebagai

Tahap Persiapan Data, dataset dengan format comma-separated values (CSV) diolah dengan menggunakan R Studio. Pada tahap ini dilakukan pemeriksaan data meliputi struktur dan keadaan data agar data menjadi siap dan dapat digunakan pada tahap berikutnya. Pemeriksaan struktur data menghasilkan penyesuaian nama atribut dan perubahan tipe data. Sedangkan pemeriksaan keadaan 
data menghasilkan penanganan nilai NULL, penanganan kelengkapan data, penghapusan atribut yang tidak dibutuhkan untuk analisis, dan penambahan atribut untuk kegiatan analisis.

Tahap Exploratory Data Analysis (EDA), dilakukan visualisasi dan analisis data secara univariate, bivariate, dan multivariate.

Tahap Insights, pada tahap ini dilakukan penarikan kesimpulan dari pola-pola dan temuan yang didapatkan dari tahap EDA.

\section{HASIL DAN PEMBAHASAN}

\subsection{Persiapan Data}

Data yang dipublikasi oleh WHO mencatatkan kejadian bunuh diri dari 101 negara dengan rentang waktu dari tahun 1985 sampai tahun 2016. Seperti dapat dilihat pada Tabel 1, pada dataset terdapat 27.820 data (baris) dan 12 kolom.

Pada tahap persiapan data, dilakukan aktifitas sebagai berikut: (i) penghapusan pada kolom yang tidak relevan dengan tujuan analisis (kolom suicides/100k pop), (ii) penghapusan kolom yang memiliki nilai NULL yang tinggi (kolom HDI for year memiliki $70 \%$ nilai $N U L L$ ), (iii) perbaikan penamaan kolom (country-year, gdp_for year (\$), gdp_per_capita (\$)), (iv) penambahan kolom benua (continent), (v) perapihan isi data pada kolom age dengan menghilangkan kata "year" dan kolom sex dengan mengstandarkan isian menjadi "Male" dan "Female", serta (vi) memberikan sifat ordinal pada kolom age dan generation. Gambar 2 menunjukkan struktur dataset setelah dilakukan tahap persiapan data.

Tabel 1 Daftar Kolom Pada Dataset Awal

\begin{tabular}{cllcr}
\hline No & Nama Kolom & Tipe & $\begin{array}{c}\text { Jumlah } \\
\text { Data }\end{array}$ & $\begin{array}{c}\text { Jumlah } \\
\text { NULL }\end{array}$ \\
\hline 1 & country & character & 27.820 & - \\
\hline 2 & year & numeric & 27.820 & - \\
\hline 3 & sex & character & 27.820 & - \\
\hline 4 & age & character & 27.820 & - \\
\hline 5 & suicides_no & numeric & 27.820 & - \\
\hline 6 & population & numeric & 27.820 & - \\
\hline 7 & $\begin{array}{l}\text { suicides/100k } \\
\text { pop }\end{array}$ & numeric & 27.820 & - \\
\hline 8 & country-year & character & 27.820 & - \\
\hline 9 & HDIforyear & numeric & 8.364 & 19.456 \\
\hline 10 & gdp_for_year $(\$)$ & numeric & 27.820 & - \\
\hline 11 & $\begin{array}{l}\text { gdp_per_capita } \\
\text { (\$) }\end{array}$ & numeric & 27.820 & - \\
\hline 12 & generation & character & 27.820 & - \\
\hline & & & & - \\
\hline
\end{tabular}

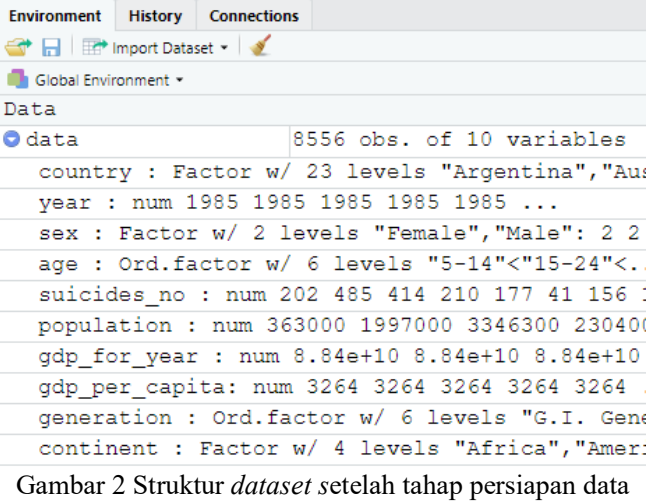

Gambar 2 Struktur dataset setelah tahap persiapan data

Dari data yang ada pada dataset, tidak semua negara memiliki kelengkapan data yang sama. Hanya 23 negara saja yang memiliki data yang lengkap sejak tahun 1985 sampai 2015. Berdasarkan hal tersebut, penulis hanya menggunakan data kejadian bunuh diri dari negara yang memiliki kelengkapan data selama 30 tahun (sejak tahun 1985 sampai 2015). Daftar negara yang memiliki kelengkapan data selama 30 tahun dapat dilihat pada Tabel 2 .

Tabel 2 Daftar Negara yang Memiliki Data Sejak Tahun 1985 -

\begin{tabular}{|c|c|c|}
\hline No & Negara & Benua \\
\hline 1 & Israel & Asia \\
\hline 2 & Japan & Asia \\
\hline 3 & Republic of Korea & Asia \\
\hline 4 & Singapore & Asia \\
\hline 5 & Mauritius & Africa \\
\hline 6 & Argentina & Americas \\
\hline 7 & Brazil & Americas \\
\hline 8 & Chile & Americas \\
\hline 9 & Colombia & Americas \\
\hline 10 & Ecuador & Americas \\
\hline 11 & Mexico & Americas \\
\hline 12 & Puerto Rico & Americas \\
\hline 13 & United States & Americas \\
\hline 14 & Austria & Europe \\
\hline 15 & Belgium & Europe \\
\hline 16 & Greece & Europe \\
\hline 17 & Iceland & Europe \\
\hline 18 & Italy & Europe \\
\hline 19 & Luxembourg & Europe \\
\hline 20 & Malta & Europe \\
\hline 21 & Netherlands & Europe \\
\hline 22 & Spain & Europe \\
\hline 23 & United Kingdom & Europe \\
\hline
\end{tabular}

Hanya ada 16 negara yang memiliki data kejadian bunuh diri pada tahun 2016. Data terebut 
tidak lengkap karena seharusnya setiap negara memiliki 12 baris pada setiap tahunnya. Dua belas baris ini didapatkan dari kombinasi jenis kelamin (Male dan Female) dan kelompok usia ("5-14", "1524", "25-34", "35-54", "55-74", "75+"). Berdasarkan keadaan ini penulis tidak memasukan data tahun 2016 untuk dianalisis.

\subsection{Visualisasi dan Analisis Data Bunuh Diri}

Gambar 3 menunjukkan proporsi jumlah bunuh diri yang terjadi pada benua Asia, Afrika, Eropa, dan Amerika selama rentang waktu 1985 - 2015. Diagram pada Gambar 3 dibuat dengan menggunakan library ggplot dengan perintah sebagai berikut:

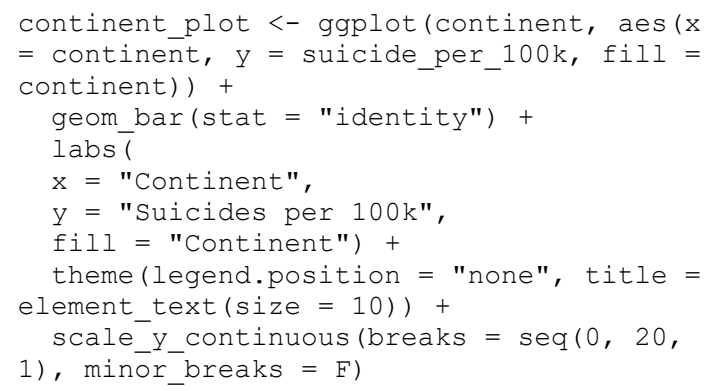

Dari Gambar 3 dapat disimpulkan bahwa benua Asia memiliki jumlah kematian yang disebabkan oleh bunuh diri paling tinggi dibandingkan dengan tiga benua lainnya, yaitu 20.6 per 100.000 populasi. Jumlah ini masih lebih besar dari total kematian di benua Eropa (9.0 per 100.000 populasi) dan Amerika (8.4 per 100.000 populasi).

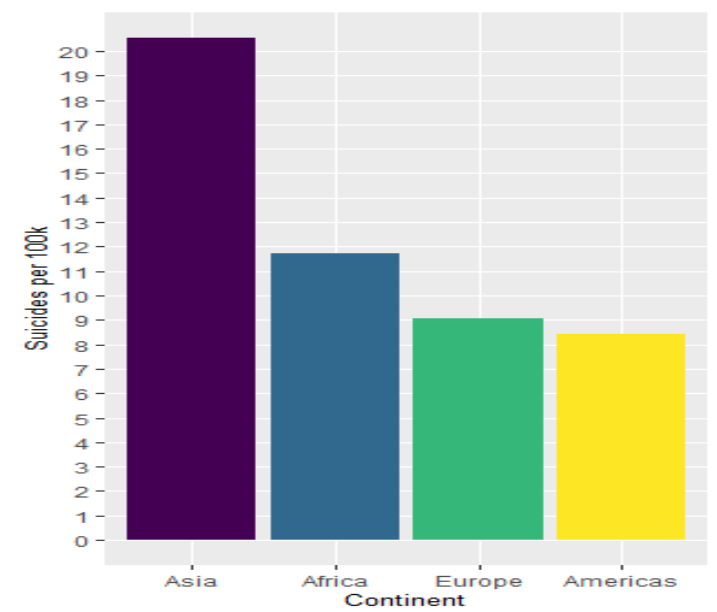

Gambar 3 Proporsi jumlah bunuh diri berdasarkan benua

Gambar 4 menunjukkan tren kejadian bunuh diri selama rentang waktu tiga puluh tahun. Diagram pada Gambar 4 dibuat dengan menggunakan library ggplot dengan perintah sebagai berikut:

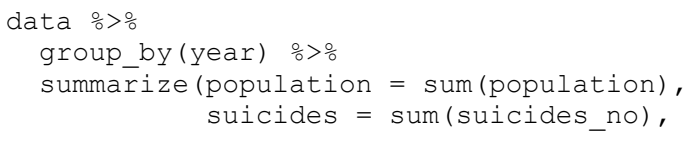

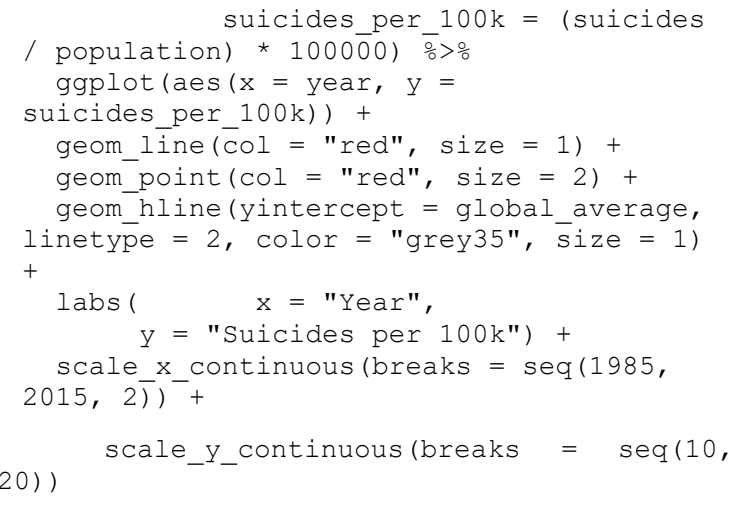

Kejadian kematian yang disebabkan karena bunuh diri memiliki dua kelompok tren, yaitu tren menurun yang terjadi pada tahun 1985 sampai 1991, dan tren menaik yang terjadi pada tahun 1991 sampai 2015. Pada tahun 1985, jumlah kejadian bunuh diri adalah 10.5 per 100.000 populasi dan meningkat sebanyak 0.3 pada tahun 1986 menjadi 10.8 per 100.000 populasi. Angka ini mengalami penurunan dan mencapai titik terendah pada tahun 1991, yaitu menjadi 9.6 per 100.000 populasi (turun sebesar 0.9 poin). Sejak tahun 1991, tren kematian yang disebabkan bunuh diri mengalami peningkatan yang cukup signifikan walaupun pada tahun-tahun tertentu jumlahnya menurun. Berdasarkan data yang ada, tahun 2011 mencatatkan jumlah kematian tertinggi, yaitu 11.65 per 100.000 populasi, atau meningkat sebesar 2 poin dalam rentang waktu 20 tahun. Dari 30 tahun data yang ada, tahun 1998 merupakan tahun yang mencatatkan peningkatan jumlah kematian yang sangat signifikan, yaitu meningkat sebesar 1.1 poin hanya dalam satu tahun saja (dengan kata lain, terjadi 12 kasus bunuh diri setiap jamnya).

Tren kejadian bunuh diri berdasarkan benua ditampilkan dalam Gambar 5. Diagram pada Gambar 5 dibuat dengan menggunakan library ggplot dengan perintah sebagai berikut:

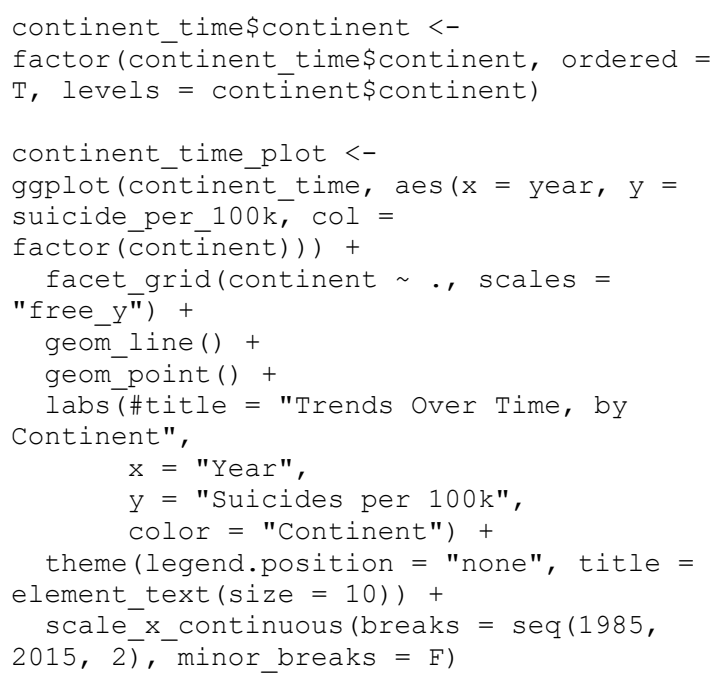




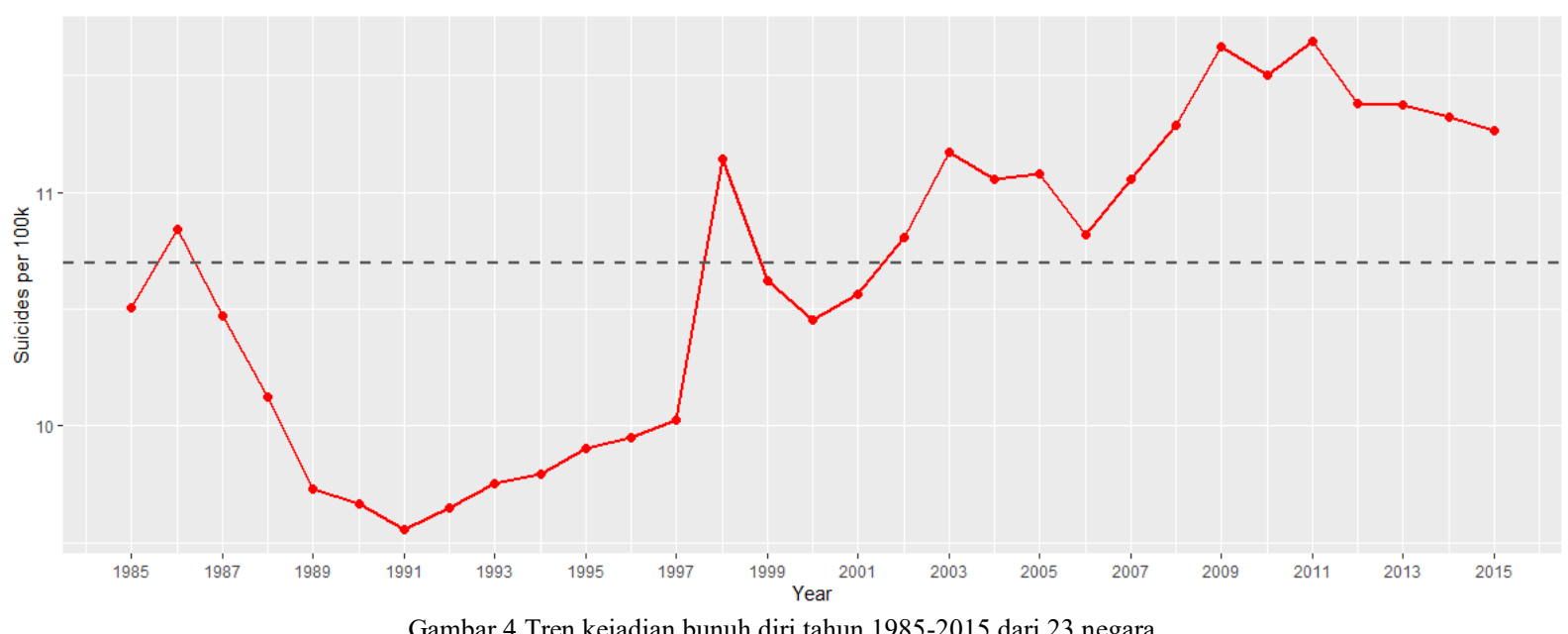

Benua Asia memiliki tren kejadian yang cenderung menaik. Kejadian paling rendah adalah pada tahun 1991 dengan 14.4 kejadian per 100.000 populasi dan paling tinggi pada tahun 2009 dengan 26.2 kejadian per 100.000 populasi (meningkat 11.8 poin dalam 18 tahun). Pada tahun 1998 terjadi peningkatan jumlah kejadian bunuh diri yang signifikan, meningkat sebesar 6.1 per 100.000 populasi. Hal ini disebabkan karena terjadinya krisis ekonomi di negara-negara asia pada tahun tersebut (Chang et al. 2009).

Benua Afrika memiliki tren kejadian bunuh diri yang fluktuatif, namun cenderung menurun. Terjadi peningkatan kejadian yang sangat signifikan pada tahun 1986 - 1987, mencatatkan peningkatan kejadian dari 3.1 kejadian per 100.000 populasi menjadi 15.4 kejadian per 100.000 populasi. Benua Eropa memiliki tren menurun dan mencapai titik terendah pada tahun 2007 dengan 7.9 kejadian per 100.000 populasi. Namun sejak tahun tersebut, tren kejadian bunuh diri terus menaik. Benua Amerika secara umum memiliki tren yang terus menaik. Dari data yang ada, jumlah kejadian bunuh diri pada tahun 2015 merupakan yang paling tinggi dibandingkan dengan tahun-tahun sebelumnya, yaitu 9.7 kejadian per 100.000 populasi.

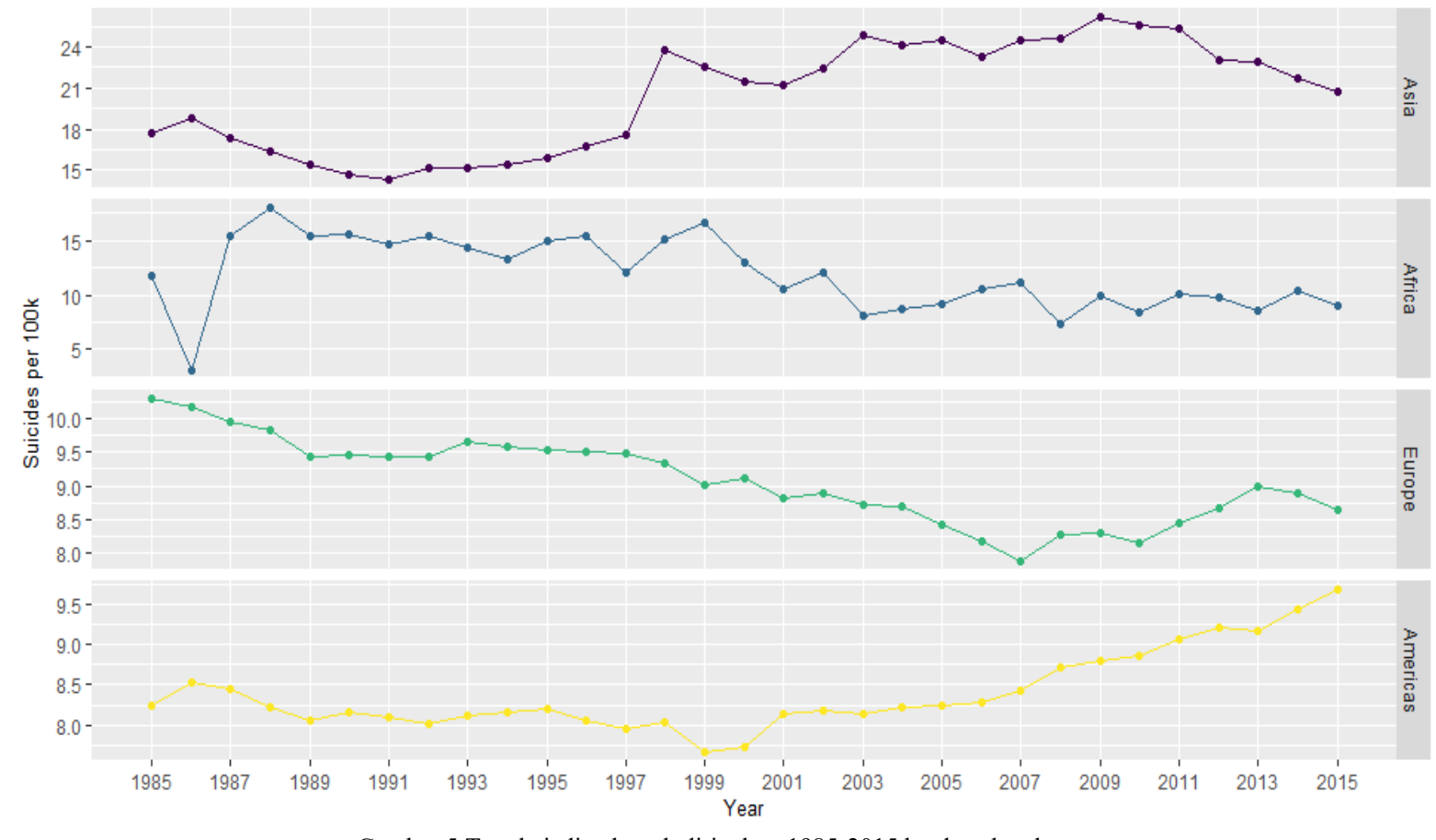

Gambar 5 Tren kejadian bunuh diri tahun 1985-2015 berdasarkan benua

Gambar 6 menunjukkan proporsi kejadian bunuh diri berdasarkan negara. Diagram pada Gambar 6 dibuat dengan menggunakan library ggplot dengan perintah sebagai berikut:

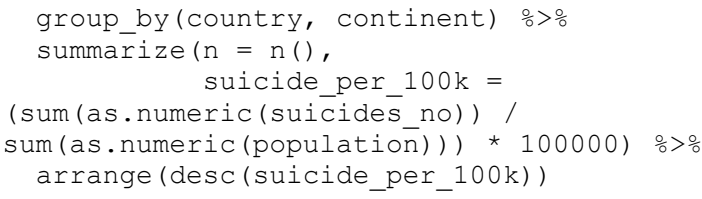


450 Jurnal Teknologi Informasi dan Ilmu Komputer (JTIIK), Vol. 8, No. 3, Juni 2021, hlm. 445-456

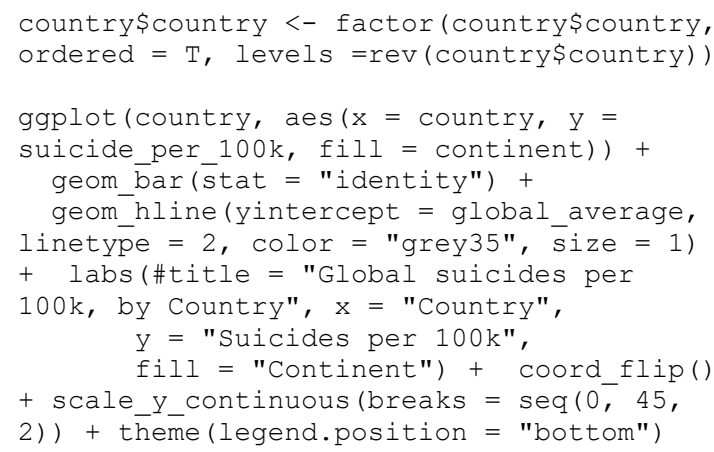

Nilai rata-rata kejadian bunuh diri dari dua puluh tiga negara adalah 10.7 kejadian per 100.000 populasi. Terdapat delapan negara yang memiliki jumlah kejadian diatas rata-rata, yaitu Jepang, Belgia, Austria, Republik Korea, Luxembourg, Iceland, Amerika Serikat, dan Mauritius. Jepang merupakan negara dengan jumlah kejadian paling tinggi di benua Asia dengan 21.9 kejadian per 100.000 populasi, Belgia paling tinggi di benua Eropa dengan 20.7 kejadian per 100.000 populasi, Amerika Serikat paling tinggi di benua Amerika dengan 12.8 kejadian per 100.000 populasi, dan Mauritius paling tinggi di benua Afrika dengan 11.7 kejadian per 100.000 populasi. Data lengkap dapat dilihat pada Tabel 3.
Tabel 3 Urutan Negara Berdasarkan Jumlah Bunuh Diri

\begin{tabular}{|c|c|c|c|}
\hline No & Negara & Benua & $\begin{array}{l}\text { Bunuh Diri per } \\
\text { 100.000 Populasi }\end{array}$ \\
\hline 1 & Japan & Asia & 21.920 .580 \\
\hline 2 & Belgium & Europe & 20.692 .535 \\
\hline 3 & Austria & Europe & 20.676 .193 \\
\hline 4 & Republic of Korea & Asia & 19.316 .652 \\
\hline 5 & Luxembourg & Europe & 15.116 .007 \\
\hline 6 & Iceland & Europe & 13.121 .794 \\
\hline 7 & United States & Americas & 12.838 .459 \\
\hline 8 & Mauritius & Africa & 11.709 .011 \\
\hline 9 & Singapore & Asia & 10.705 .368 \\
\hline 10 & Netherlands & Europe & 10.614 .768 \\
\hline 11 & Chile & Americas & 9.563 .284 \\
\hline 12 & Puerto Rico & Americas & 8.580 .785 \\
\hline 13 & Spain & Europe & 8.162 .025 \\
\hline 14 & Argentina & Americas & 7.936 .309 \\
\hline 15 & United Kingdom & Europe & 7.867 .928 \\
\hline 16 & Italy & Europe & 7.700 .095 \\
\hline 17 & Israel & Asia & 6.525 .616 \\
\hline 18 & Ecuador & Americas & 6.000 .093 \\
\hline 19 & Malta & Europe & 5.210 .466 \\
\hline 20 & Colombia & Americas & 4.790 .865 \\
\hline 21 & Brazil & Americas & 4.666 .570 \\
\hline 22 & Mexico & Americas & 4.007 .957 \\
\hline 23 & Greece & Europe & 3.912 .734 \\
\hline
\end{tabular}

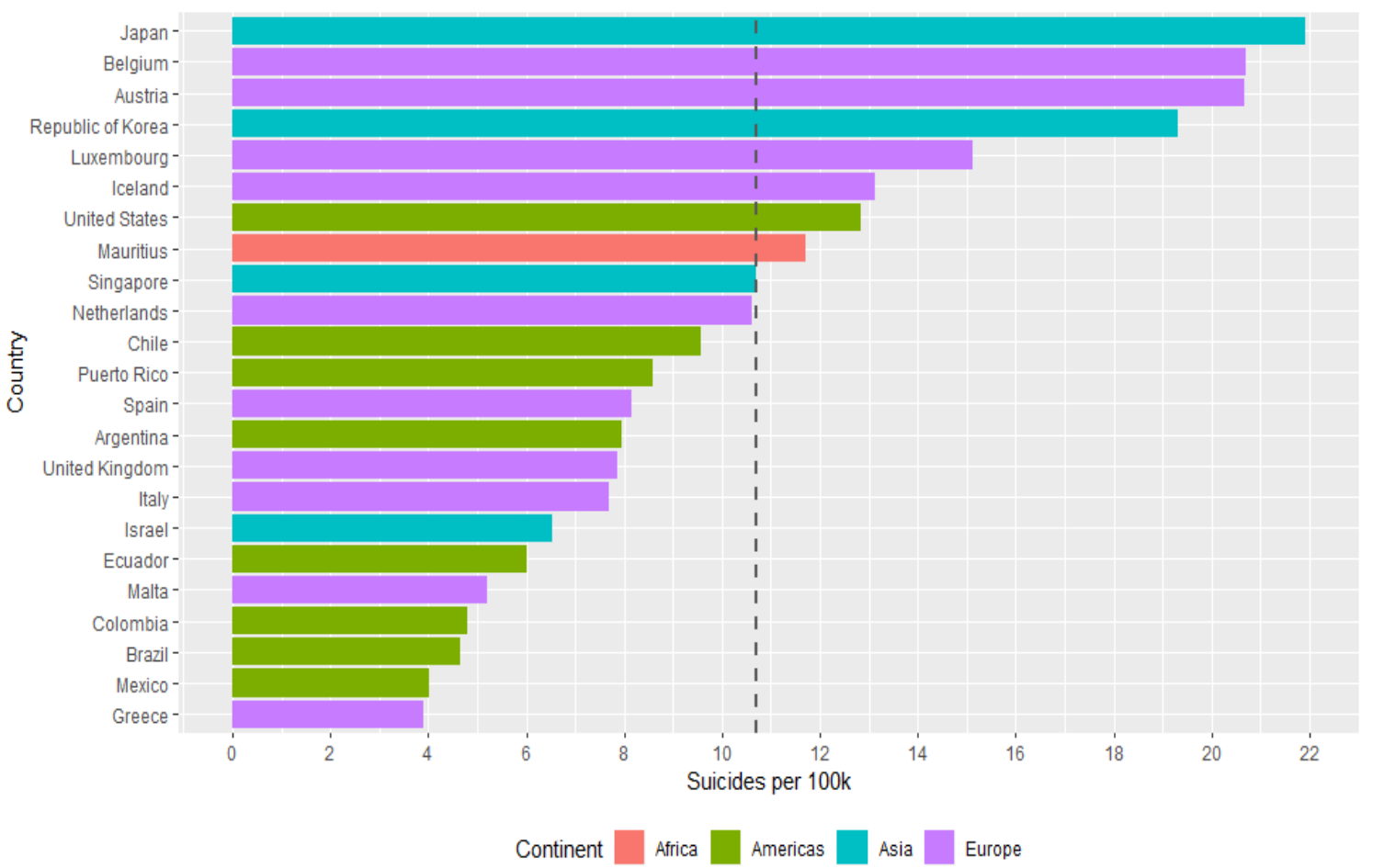

Gambar 6 Proporsi jumlah bunuh diri berdasarkan negara 
Gambar 7 merepresentasikan perbandingan kejadian bunuh diri berdasarkan jenis kelamin. Diagram pada Gambar 7 dibuat dengan menggunakan library ggplot dengan perintah sebagai berikut:

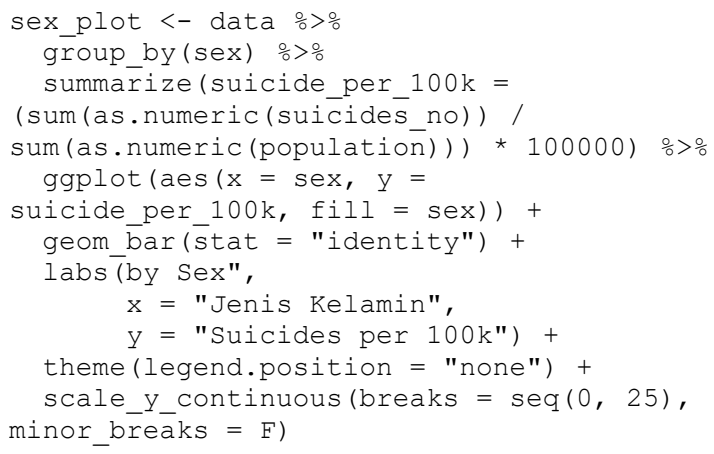

Jumlah kejadian bunuh diri yang dilakukan oleh Laki-Laki hampir tiga kali lebih banyak dari yang dilakukan oleh Perempuan.

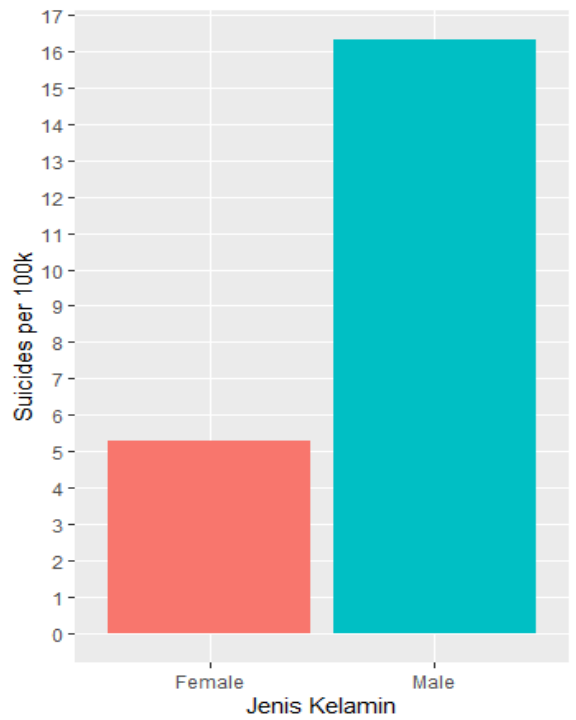

Gambar 7 Perbandingan kejadian bunuh diri berdasarkan jenis kelamin

Gambar 8 menunjukkan proporsi kejadian bunuh diri berdasarkan jenis kelamin dari setiap benua. Diagram pada Gambar 8 dibuat dengan menggunakan library ggplot dengan perintah sebagai berikut:

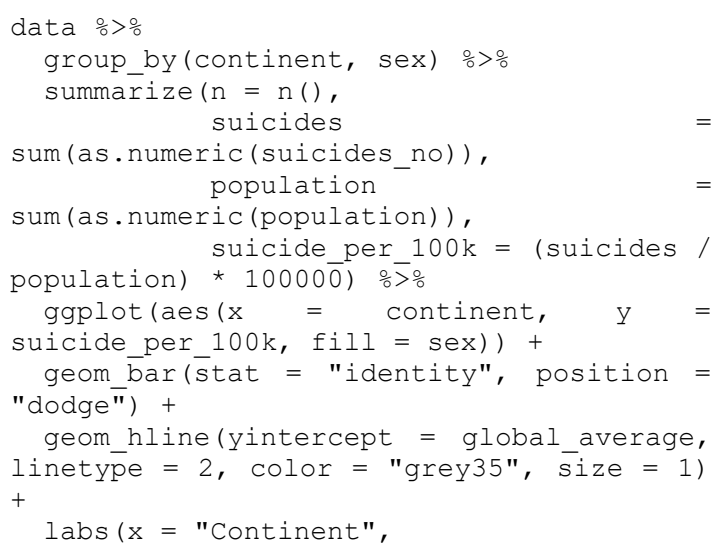

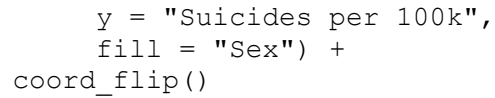

Dari Gambar 8 dapat dilihat bahwa Laki-laki merupakan pelaku bunuh diri yang paling banyak di setiap benua dan jumlahnya semua diatas rata-rata. Untuk pelaku bunuh diri dengan jenis kelamin Perempuan, hanya benua Asia saja yang jumlah kejadiannya diatas rata-rata.

Gambar 9 menunjukkan tren kejadian bunuh diri berdasarkan jenis kelamin dari tahun 1985 sampai 2015. Diagram pada Gambar 9 dibuat dengan menggunakan library ggplot dengan perintah sebagai berikut:

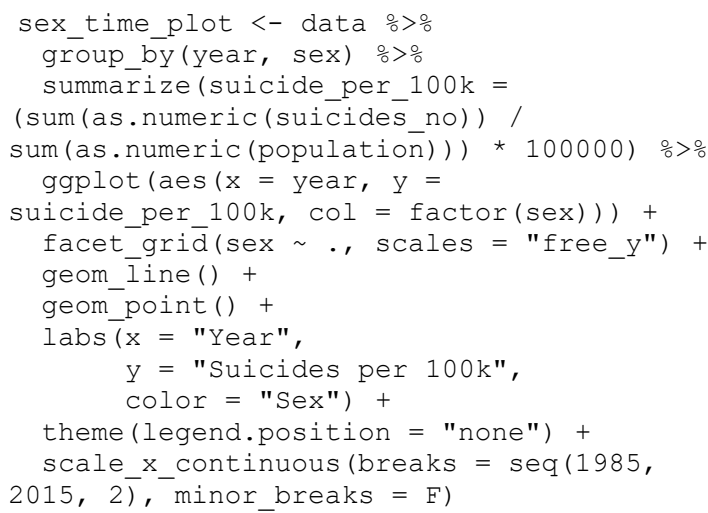

Pelaku bunuh diri dengan jenis kelamin Perempuan paling banyak terjadi pada Tahun 1986. Angka ini terus menurun dan mencapai angka terrendah pada tahun 1994, turun sebesar 1.2 per 100.000 populasi. Dari tahun 1985 sampai 2015 terjadi peningkatan tren namun jumlahnya masih dibawah tahun 1986. Untuk kejadian bunuh diri dengan jenis kelamin Laki-laki, memiliki tren yang menaik.

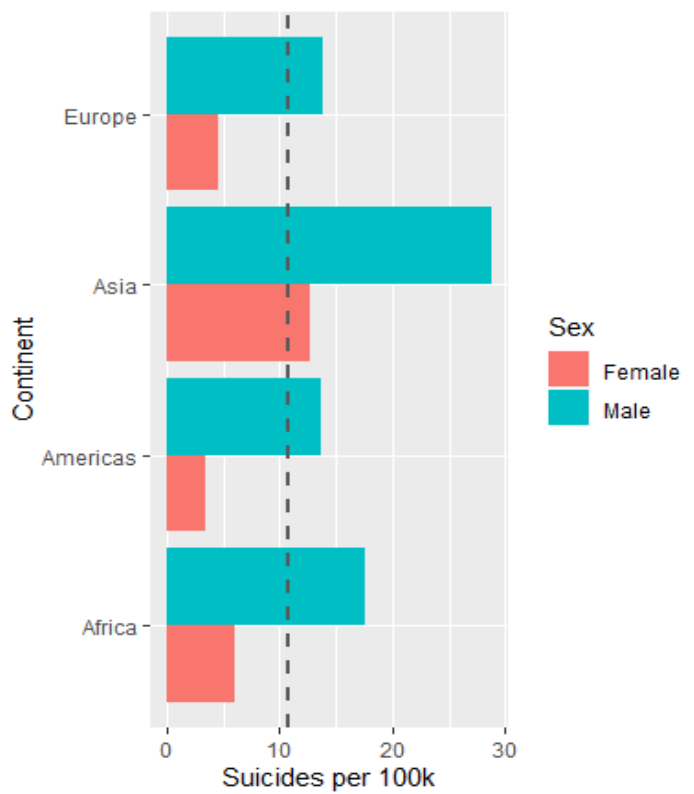

Gambar 8 Perbandingan kejadian bunuh diri berdasarkan jenis kelamin dan benua 


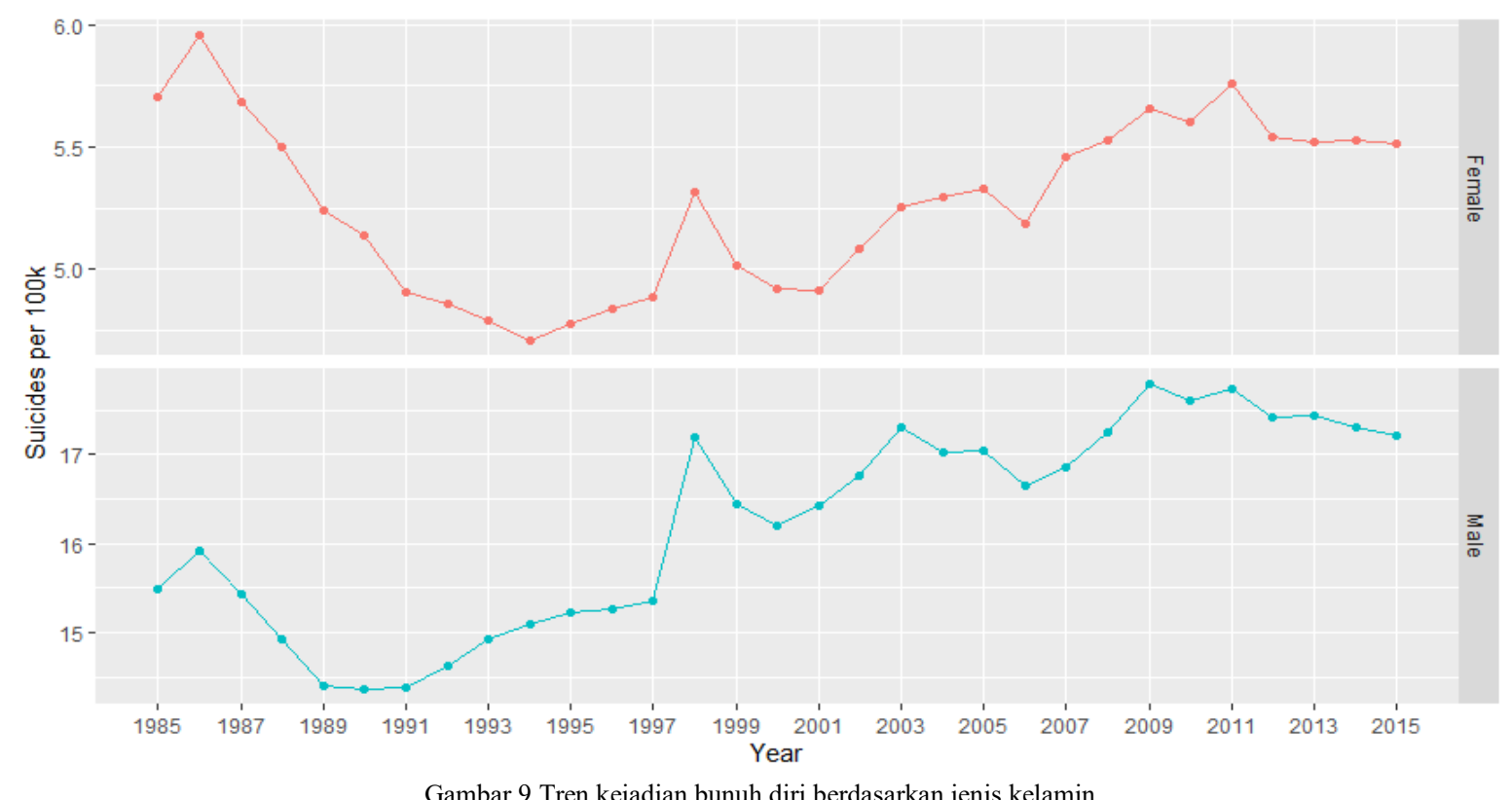

Gambar 10 menunjukkan perbandingan jumlah kejadian bunuh diri berdasarkan kelompok umur. Diagram pada Gambar 10 dibuat dengan menggunakan library ggplot dengan perintah sebagai berikut:
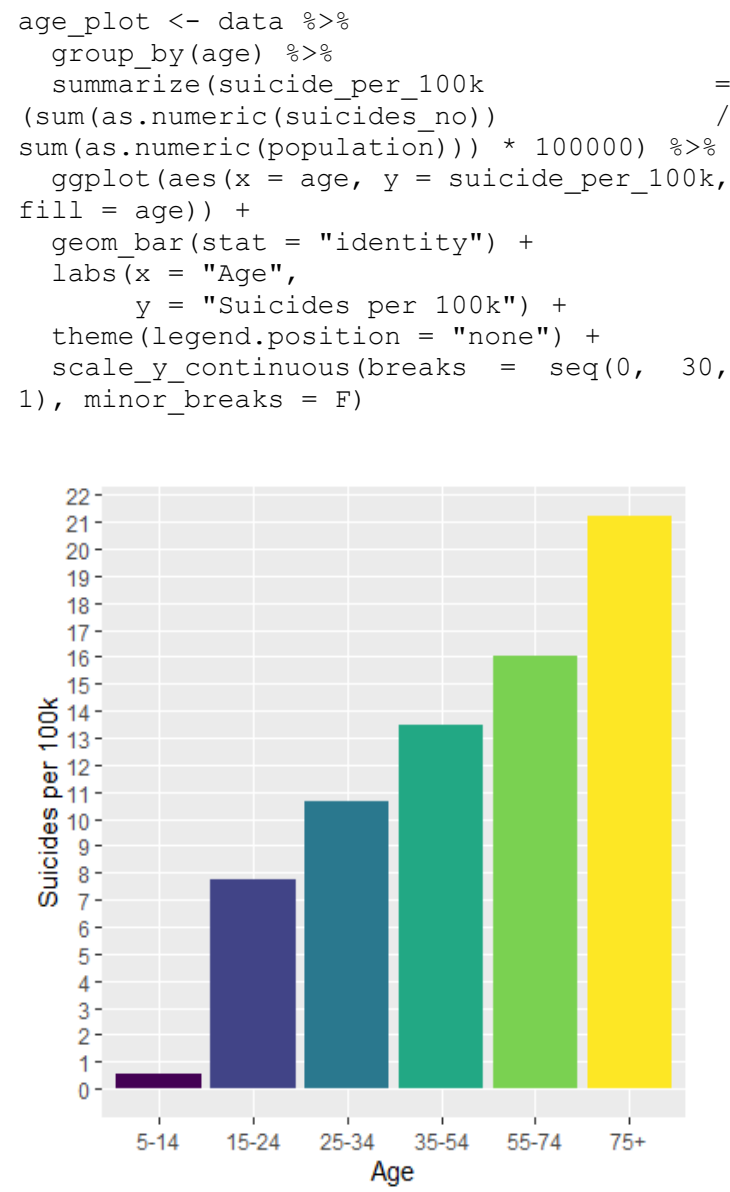

Gambar 10 Jumlah bunuh diri berdasarkan kelompok umu

Terdapat lima kelompok umur yang didefinisikan dalam data, yaitu 5-14 tahun, $15-24$ tahun, 25 - 34 tahun, 35 - 54 tahun, 55 - 74 tahun, dan diatas 75 tahun. Berdasarkan data yang ada, kelompok umur diatas 75 tahun merupakan kelompok umur dengan pelaku bunuh diri paling banyak.

Gambar 11 menggambarkan jumlah bunuh diri berdasarkan kelompok umur di setiap benua. Diagram pada Gambar 11 dibuat dengan menggunakan library ggplot dengan perintah sebagai berikut:

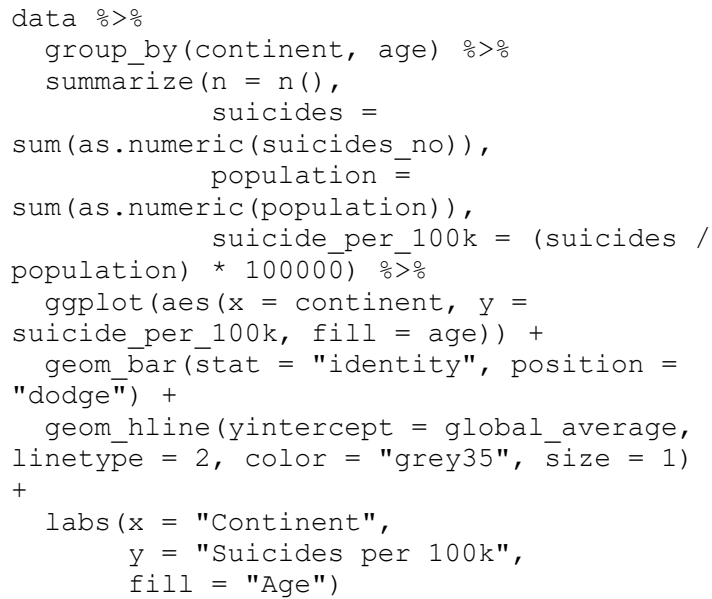

Kelompok umur 5-14 tahun memiliki jumlah kejadian paling sedikit di semua benua. Kelompok umur 15-24 tahun, hanya di benua Afrika saja yang jumlahnya melebihi angka rata-rata. Kelompok umur 25-34 tahun di benua Afrika merupakan kelompok umur dengan jumlah bunuh diri paling banyak dibandingkan dengan kelompok umur lainnya. Kelompok umur diatas 75 tahun di benua Amerika, Asia, dan Eropa, merupakan kelompok umur yang paling tinggi jumlah bunuh dirinya. Sedangkan di benua Afrika merupakan kelompok umur kedua terendah. 


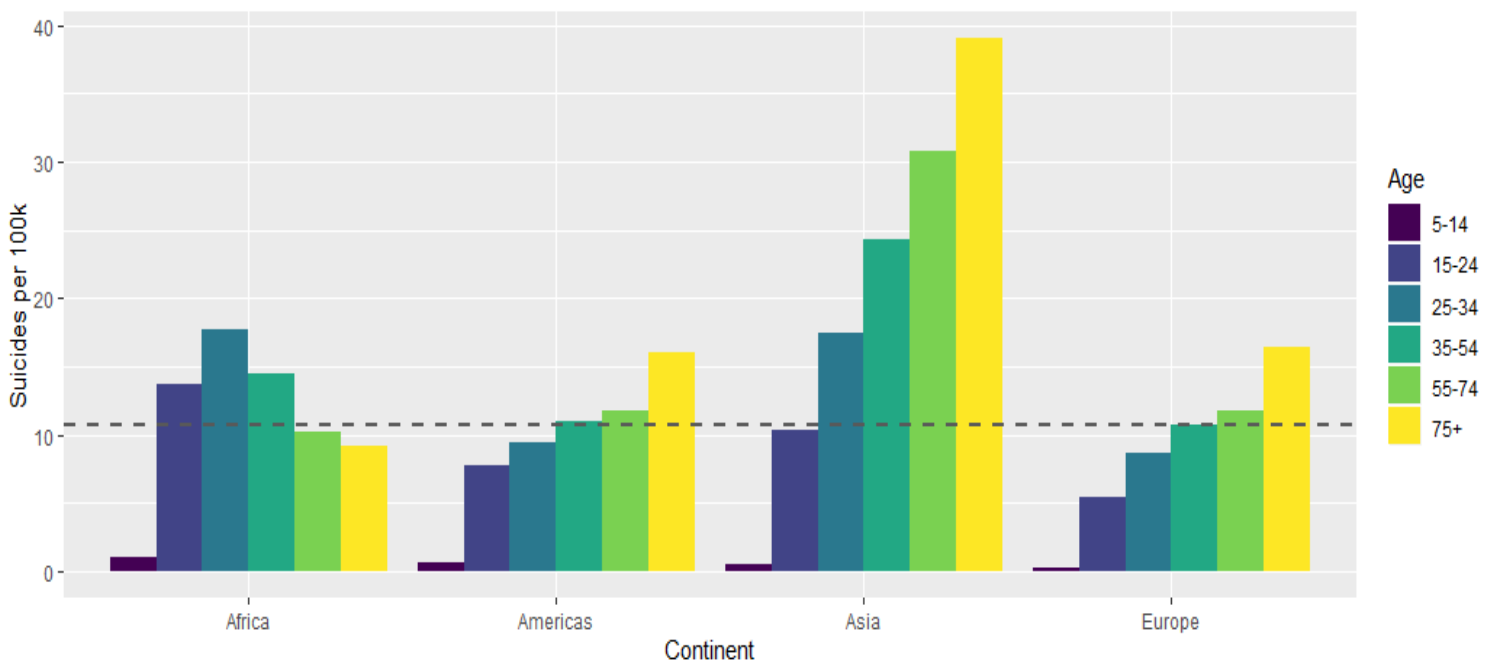

Gambar 11 Proporsi jumlah bunuh diri berdasarkan kelompok umur dan benua

Gambar 12 memperlihatkan tren kejadian bunuh diri berdasarkan kelompok umur pada rentang waktu tiga puluh tahun. Diagram pada Gambar 12 dibuat dengan menggunakan library ggplot dengan perintah sebagai berikut:

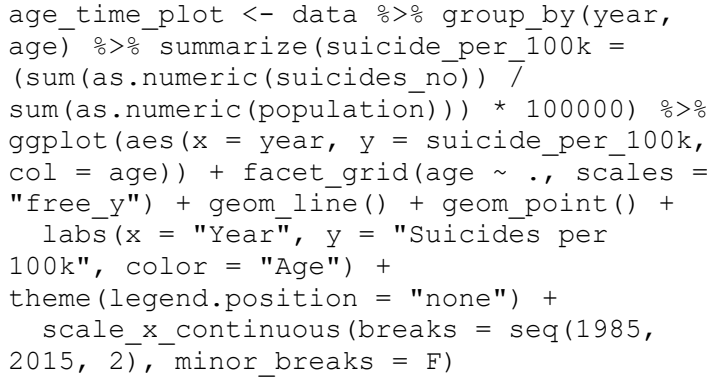

Kelompok umur 5-14 tahun memiliki tren menaik dan mencapai angka tertinggi pada tahun 2014. Kelompok umur 15-24 tahun juga memiliki tren yang terus menaik dan mencapai puncaknya pada tahun 2015. Kelompok umur 25-34 tahun memiliki tren yang fluktuatif tetapi cenderung menaik. Terjadi lonjakan kejadian bunuh diri pada tahun 1986, 1998, dan mencapai angka tertinggi pada tahun 2011.

Kelompok umur 35-54 tahun memiliki tren yang menaik sejak tahun 1992. Kelompok umur ini juga mengalami lonjakan kejadian bunuh diri pada tahun 1998. Kejadian bunuh diri tertinggi terjadi pada tahun 2009, dan pada tahun-tahun selanjutnya mulai menurun. Kelompok umur 55-74 tahun memiliki dua fase penurunan tren, pada tahun 1985 sampai 1994 dan tahun 1999 sampai 2015. Sama seperti kelompok umur 25-34 dan 35-54 tahun, kelompok umur ini memiliki lonjakan kejadian bunuh diri pada tahun 1998, namun lonjakan yang terjadi pada kelompok umur ini lebih tinggi bila dibandingkan dengan kelompok umur 25-34 dan 35-54 tahun. Berbeda dengan kelompok umur lainnya, walaupun jumlah kejadiannya masih paling tinggi, kelompok umur diatas 75 tahun memiliki tren yang menurun.
Walaupun memiliki kenaikan jumlah bunuh diri pada tahun 1998, jumlah kenaikannya tidak terlalu besar.

Gambar 13 memperlihatkan perbandingan jumlah bunuh diri berdasarkan kelompok umur dan jenis kelamin di benua Asia, Eropa, Amerika, dan Afrika. Diagram pada Gambar 13 dibuat dengan menggunakan library ggplot dengan perintah sebagai berikut:

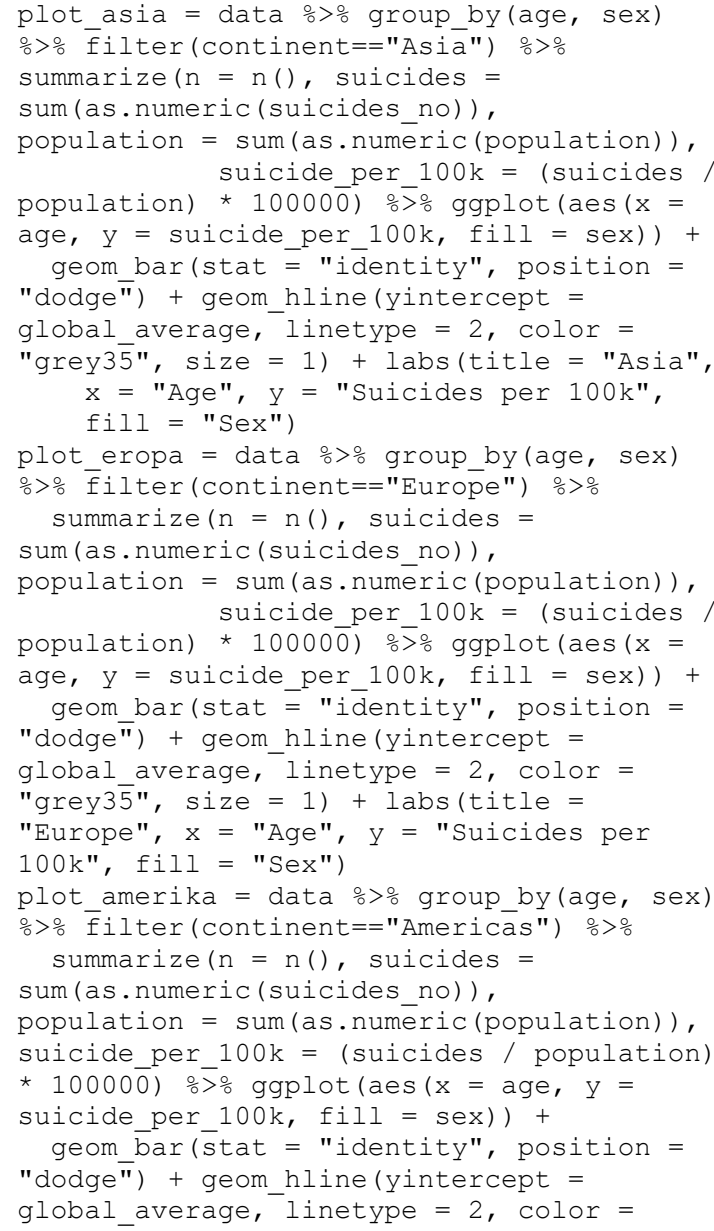




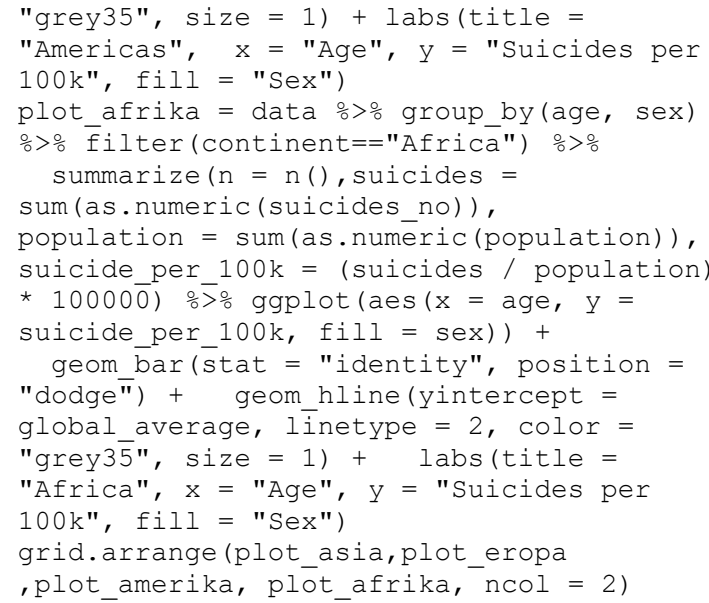

Benua Asia dan Eropa memiliki kemiripan pola dalam kelompok umur dan jenis kelamin dari pelaku bunuh diri. Benua Amerika memiliki pola yang berbeda untuk pelaku bunuh diri dengan jenis kelamin Perempuan. Perempuan dengan kelompok umur 35-54 tahun merupakan kelompok umur yang paling banyak melakukan bunuh diri dibandingkan dengan kelompok umur lainnya.

Benua Afrika memiliki pola yang berbeda dengan benua lainnya. Kelompok umur 25-34 tahun dengan jenis kelamin Laki-laki merupakan kelompok yang paling banyak melakukan bunuh diri. Untuk jenis kelamin Perempuan, tindakan bunuh diri paling banyak dilakukan oleh kelompok umur 15-24 tahun.

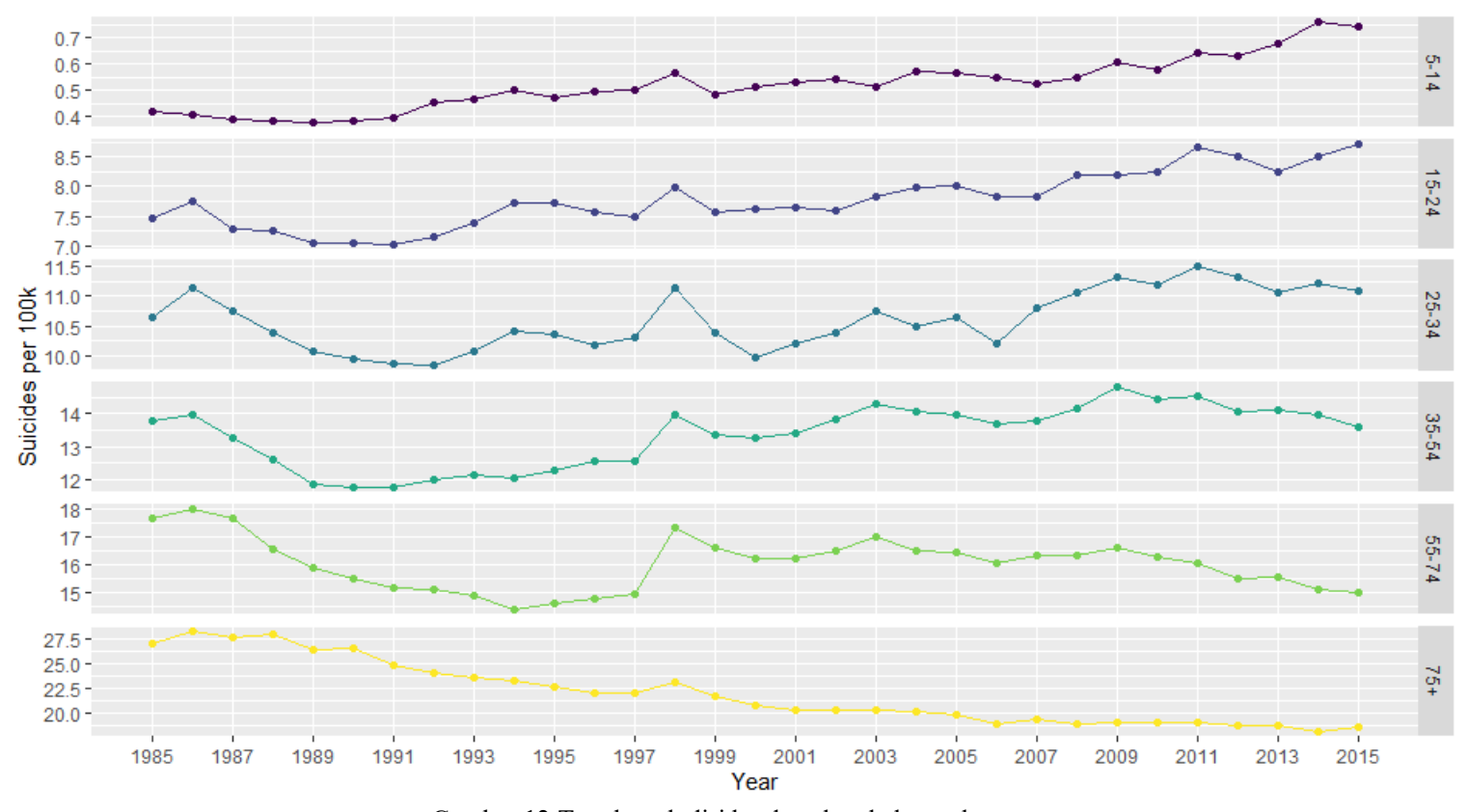

Gambar 12 Tren bunuh diri berdasarkan kelompok umur
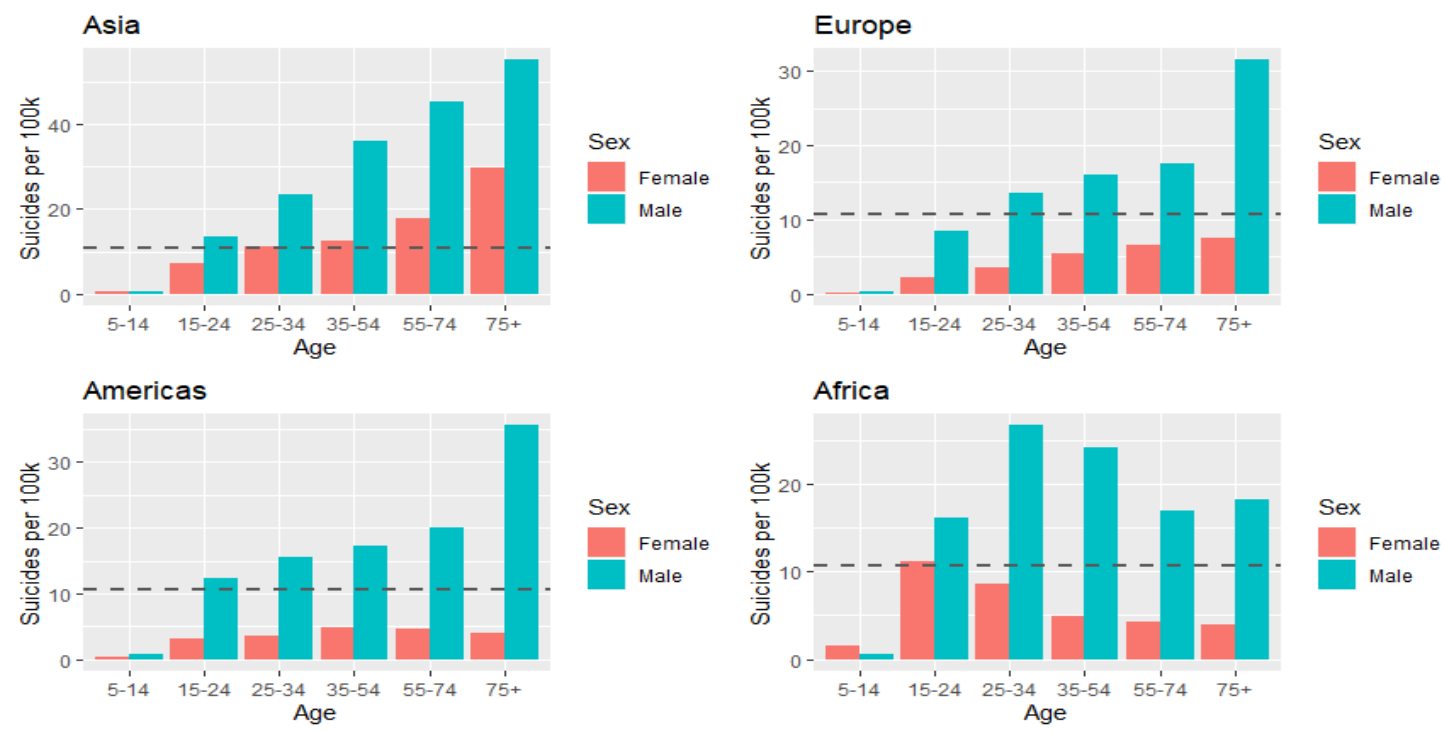

Gambar 13 Proporsi Jumlah bunuh diri berdasarkan kelompok umur dan jenis kelamin di Asia, Eropa, Amerika, dan Afrika 


\section{KESIMPULAN}

Pada penelitian ini telah dilakukan visualisasi dan analisis data kematian yang disebabkan bunuh diri dengan rentang waktu tiga puluh tahun di dua puluh tiga negara. Dapat disimpulkan bahwa dengan penyajian data secara visual, pola-pola tersembunyi dalam data dapat dengan mudah ditemukan.

Beberapa pola yang ditemukan dari penerapan Exploratory Data Analysis menunjukkan bahwa, berdasarkan data WHO, tahun 1991 merupakan tahun dengan jumlah bunuh diri terkecil, terjadi lonjakan jumlah bunuh diri di negara-negara Asia pada tahun 1998. Berdasarkan data yang ada, secara umum, jumlah bunuh diri memiliki tren yang semakin naik. Negara-negara di benua Amerika memiliki tren bunuh diri yang semakin meningkat.

Berdasarkan kelompok umur, kelompok umur diatas 75 tahun merupakan kelompok usia dengan jumlah bunuh diri paling banyak diseluruh negara yang dianalisis. Temuan lainnya adalah jumlah bunuh diri pada kelompok umur 5-14 tahun memiliki tren yang semakin meningkat. Berdasarkan pola pelaku bunuh diri, benua Afrika memiliki pola pelaku bunuh diri yang berbeda dengan benua lainnya.

Temuan-temuan yang didapatkan dari visualisasi dan analisis data kematian yang disebabkan bunuh diri dapat dimanfaatkan untuk kebutuhan perencanaan pencegahan kejadian bunuh diri dan meningkatkan kewaspadaan terhadap terjadinya risiko bunuh diri, terutama pada kelompok umur diatas 75 tahun dan 5-14 tahun.

Visualisasi dan analisis data kematian yang disebabkan bunuh diri baru dilakukan sampai tahun 2015. Hal ini terjadi dikarenakan data yang tersedia pada basis data WHO hanya sampai tahun 2016 saja dan data pada tahun 2016 masih sangat sedikit dan tidak lengkap. Bila datanya ada, visualisasi dan analisis data kematian karena bunuh diri akan lebih representatif bila dilakukan sampai akhir tahun 2019 .

\section{DAFTAR PUSTAKA}

AMMERMAN, BROOKE A., SARFARAZ SERANG, ROSS JACOBUCCI, TAYLOR A. BURKE, LAUREN B. ALLOY dan MICHAEL S. MCCLOSKEY. 2018. "Exploratory Analysis of Mediators of the Relationship between Childhood Maltreatment and Suicidal Behavior". Journal of Adolescence 69: 103-12. $<$ https://doi.org/10.1016/j.adolescence.2018.0 9.004>.

BURKE, TAYLOR A., ROSS JACOBUCCI, BROOKE A. AMMERMAN, MARILYN PICCIRILLO, MICHAEL S. MCCLOSKEY, RICHARD G. HEIMBERG dan LAUREN B. ALLOY. 2018. "Identifying the Relative Importance of Non-Suicidal Self-Injury Features in Classifying Suicidal Ideation, Plans, and Behavior Using Exploratory Data
Mining”. Psychiatry Research 262: 175-83. $<$ https://doi.org/10.1016/j.psychres.2018.01.04 $5>$.

CHANG, SHU SEN, DAVID GUNNELL, JONATHAN A.C. STERNE, TSUNG HSUEH LU dan ANDREW T.A. CHENG. 2009. "Was the Economic Crisis 1997-1998 Responsible for Rising Suicide Rates in East/Southeast Asia? A Time-Trend Analysis for Japan, Hong Kong, South Korea, Taiwan, Singapore and Thailand". Social Science and Medicine 68: 1322-31.

$<$ https://doi.org/10.1016/j.socscimed.2009.01. $010>$.

JEBB, ANDREW T., SCOTT PARRIGON dan SANG EUN WOO. 2017. "Exploratory Data Analysis as a Foundation of Inductive Research". Human Resource Management Review 27: 265-76. $<$ https://doi.org/10.1016/j.hrmr.2016.08.003>.

LUDWIG, BIRGIT, DANIEL KÖNIG, NESTOR D. KAPUSTA, VICTOR BLÜML, G. DORFFNER dan BENJAMIN VYSSOKI. 2019. "Clustering Suicides: A Data-Driven, Exploratory Machine Learning Approach". European Psychiatry 62: 15-19. $<$ https://doi.org/10.1016/j.eurpsy.2019.08.009 $>$.

LUTZ, P. E., N. MECHAWAR dan G. TURECKI. 2017. "Neuropathology of Suicide: Recent Findings and Future Directions". Molecular Psychiatry. Nature Publishing Group. $<$ https://doi.org/10.1038/mp.2017.141>.

PRETI, ANTONIO dan GIANLUCA LENTINI. 2016. "Forecast Models for Suicide: TimeSeries Analysis with Data from Italy". Chronobiology International 33: 1235-46. $<$ https://doi.org/10.1080/07420528.2016.1211 $669>$.

TURECKI, GUSTAVO dan DAVID A. BRENT. 2016. "Suicide and Suicidal Behaviour". The Lancet. Lancet Publishing Group. $<$ https://doi.org/10.1016/S01406736(15)00234-2>.

TURECKI, GUSTAVO, DAVID A. BRENT, DAVID GUNNELL, RORY C. O'CONNOR, MARIA A. OQUENDO, JANE PIRKIS dan BARBARA H. STANLEY. 2019. "Suicide and Suicide Risk". Nature Reviews Disease Primers. Nature Publishing Group. $<$ https://doi.org/10.1038/s41572-019-0121-0>.

WONGSUPHASAWAT, KANIT, YANG LIU dan JEFFREY HEER. 2019. "Goals, Process, and Challenges of Exploratory Data Analysis: An Interview Study", November. $<$ http://arxiv.org/abs/1911.00568> [accessed 21 March 2020]. 
Halaman ini sengaja dikosongkan 